\title{
Descolonizar o pensamento museológico: reintegrando a matéria para re-pensar os museus
}

Decolonizing museological thinking: reintegrating the matter to re-think museums

hitp://dx.doi.org/10.1590/1982-02672020v28e 1

\section{BRUNO BRULON ${ }^{1}$}

https://orcid.org/0000-0002-1037-8598

Universidade Federal do Estado do Rio de Janeiro / Rio de Janeiro, RJ, Brasil

RESUMO: $\bigcirc$ artigo apresenta uma reflexão com bases teóricas sobre as estruturas coloniais dos museus, considerando historicamente o desenvolvimento dessas instituições no Brasil desde a criação do Museu Nacional do Rio de Janeiro, em 1818. Propõe a descolonização do pensamento museológico por meio do reconhecimento crítico de suas bases no lluminismo e na reiteração material do sujeito racional como sujeito ontológico herdado desde o cogito cartesiano. Abordando a crítica decolonial, identifica na separação entre sujeito e objeto e entre pensamento e matéria - estruturantes do pensamento filosófico ocidental - o principal traço do colonialismo nos regimes museais e patrimoniais. Entendendo os museus como dispositivos de "materialização", segundo o conceito de Judith Butler, o artigo propõe a reintegração da matéria ao pensamento na teoria museológica como caminho para re-pensar as práticas museais em regimes pós-coloniais.

\begin{abstract}
1. Bacharel em Museologia, licenciado e bacharel em História pela Universidade Federal do Estado do Rio de Janeiro (UNIRIO); mestre pelo Programa de Pós-Graduação em Museologia e Patrimônio - UNIRIO/Mast; doutor pelo Programa de Pós-Graduação em Antropologia da Universidade Federal Fluminense (UFF). Atualmente é professor adjunto dos cursos de Museologia da UNIRIO e presidente do Comitê Internacional de Museologia ICOFOM, do ICOM. E-mail: <brunobrulon@gmail.com>
\end{abstract}

PALAVRAS-CHAVE: Museologia. Museus. Descolonização. Matéria. Materialização. 
ABSTRACT: The article presents a theoretical reflection on the colonial basis of the museum, considering its historical development in Brazil, since the creation of the National Museum (Museu Nacional) in Rio de Janeiro, in 1818. It proposes the decolonization of museological thinking by critically recognizing its foundations in the Enlightenment and in the reiteration of the rational and material subject, the ontological subject inherited since the cartesian cogito. In a decolonial approach, it identifies as the main trace of colonialism in museums and in cultural heritage the breach between subject and object, and between thinking and matter, which are structural of philosophical thinking in the West. Comprehending museums as devices for "materialization", based on the concept by Judith Butler, the paper proposes the reintegration of matter into thinking in museological theory as a path to re-thinking museum practice in post-colonial regimes.

KEY-WORDS: Museology. Museums. Decolonization. Matter. Materialization. 
Numa visão diacrônica, verifica-se que, esboçada a paisagem museológica brasileira, se pode sentir a existência de um passado que, certamente, existe, mas não sedimentou suficientemente. Talvez, pela razão mesma de ter, o Museu, se antecipado - como instituição - à própria Independência, carregando, assim, consigo, muito de uma mentalidade colonial ou colonizada. ${ }^{2}$

Uma sala de museu é palco para a encenação de identidades forjadas por relações de poder sedimentadas pelo tempo desde a colonização. Paredes e vitrines, em suas divisões retilíneas, decompõem o mundo em seus fragmentos para a compreensão visando a dominação de seu conjunto. Os museus, ao encenar o Outro construindo distâncias invisíveis entre quem vê e quem é visto, quem produz e quem consome, ou quem pensa e quem é objeto de pensamento, materializam, nos regimes de colonialidade herdados de um passado pouco contestado, os patrimônios valorados no presente.

Museus não são feitos só de paredes. Seus objetos são investidos de um discurso encenado por certos atores. Suas vitrines são o resultado de escolhas de outros. Aquilo que materializam é produto de um processo complexo e politicamente determinado que intitulamos teoricamente de musealização. Musealizar é uma forma de construir consenso sobre o valor e sobre a matéria, se percebemos que os museus são instituições organicamente ligadas às sociedades. É a sociedade que produz o valor transmitido pelos museus. Mas, como dispositivos, em sua maioria, criados por um Estado cuja centralidade, no caso brasileiro, não deixou escapar o patrimônio cultural, ao mesmo tempo em que produzem valor, museus são o resultado de negociações do próprio consenso sobre o valor, reproduzindo materialmente as hierarquias de poder e saber que conformam aquilo que se entende por Nação.

O exercício ao qual nos propomos no presente artigo é o de pensar criticamente o próprio pensamento construído a partir dos museus e que engendrou - que se entende hoje por Museologia no Brasil. Tal empreitada não pode ser alcançada sem o devido entendimento histórico da importação dessas instituições para a colônia, e dos valores produzidos desde a criação do primeiro museu imperial, há 200 anos. O Museu Nacional do Rio de Janeiro, criado em 1818 , marcou, no contexto de um império com sede nos trópicos, a continuidade política e cultural da metrópole na distância da colônia. No século XIX, ele configurou um modelo de produção e disseminação do conhecimento a partir de coleções 
3. Termo cunhado por Zbyněk Z. Stránsky para se referir ao valor ou qualidade documental dos objetos que passam pelo processo de musealização. Sobre tal conceito na obra de Stránsky, cf. Brulon (2017).

4. Sobre o conceito de "colonialidade do poder e do saber" cf. Quijano (2000); Mignolo (2007).

5. A discussão sobre o uso colonial dos museus para a produção de conhecimento sobre as colônias não é recente e apresenta marcos significativos na Antropologia. Nas últimas décadas do século $\mathrm{XX}$, diversos autores estabeleceram uma mirada crítica sobre a própria disciplina, estudando sua teoria e seus métodos a partir do ponto de vista dos encontros coloniais. Como sintetizado por Talal Asad (1973), estes devem partir do fato de que a realidade básica que fez da antropologia social, no início do século XX, "uma empresa efetiva" foi a relação de poder entre culturas dominadoras (a europeia) e dominadas (as não europeias). É com base neste princípio que os museus, como instituições coloniais de produção de conhecimento, vão se espalhar no mundo, tendo como centro e modelo prático as instituições europeias. organizadas e classificadas segundo critérios formulados com base em trocas internacionais, fabricando uma musealidade ${ }^{3}$ pautada na colonialidade. ${ }^{4}$

Instituição de pesquisa e educação cuja perda irreparável a sociedade brasileira sentiu com lágrimas após o incêndio do dia 2 de setembro de 2018, o Museu Nacional, atualmente ligado à Universidade Federal do Rio de Janeiro (UFRJ), foi, ao longo de sua história, o substrato para a invenção de outras museologias possíveis. Sua imponência foi nosso baluarte. Fizemos dele símbolo e mártir, herói e anti-herói de uma museologia que ousou se autoquestionar. $\bigcirc$ Museu Nacional foi nossa morada, para que pudéssemos, nos últimos 200 anos, pensar sobre os seus alicerces. Sua matéria foi nosso escudo. Hoje, suas ruínas são o corpo de nossas ciências, dilacerado pela perda de suas partes irrecuperáveis. Fazemos dele, na presente análise, símbolo de uma museologia reflexiva, que se volta para suas próprias bases pensando os regimes de valor que produzem patrimônios e materialidades.

Partindo do Museu Nacional e de suas coleções cientifícas como expressões do paradigma da ciência enciclopédica que fundou o campo museal no Brasil, constatamos que a história do pensamento no dito "Ocidente", em grande medida, se vê atravessada pela história dos museus na Modernidade, ao longo da qual foram suprimidas outras formas de experimentar e de pensar o mundo em detrimento de um único pensar universal. Na presente análise, nos propomos a partir do pensamento sobre os museus para alcançar o exercício reflexivo de pensar o pensamento museológico - isto é, o pensamento da Museologia que abarca a reflexão sobre os próprios regimes de valor que produzem museus e patrimônios. Tal exercício implica, primeiramente, no ato decolonial de decompor o próprio pensamento.

Historicamente, o artifício da razão e a supremacia do logos já estavam na base da forma de pensar preconizada pelos museus criados há dois séculos e dariam origem ao que se passaria a entender como museologia no Brasil. Não se pode ignorar, pensando o pensamento sobre museus na passagem ao século XIX, que estes chegam nas colônias como instrumentos do projeto imperial de produção de conhecimentos e difusão das ciências. ${ }^{5}$ De certa forma encenando as nações no contexto do Hemisfério Sul, os museus imperiais do século XIX funcionavam como estandartes das viagens dos séculos anteriores. Enquanto os "novos mundos" já faziam parte dos gabinetes dos príncipes, as coleções reais passariam a fazer parte dos contextos coloniais, notadamente no caso brasileiro, com a transferência da corte portuguesa, em 1808. Nesse contexto, o conhecimento produzido pelos museus tinha um centro de difusão, e a ideia de civilização demarcava hierarquias sociais e distinções culturais com base em definições políticas do mundo colonialista.

Ao nos colocarmos a pensar o próprio pensamento que fundou museus, que erigiu patrimônios e que moldou os limites axiológicos de um campo de exclusões 
de subjetividades que não se materializaram, propomos desafiar o pensamento racional iluminista para encontrar saídas imaginativas que permitam produzir uma nova ordem material. Assim, a descolonização do pensamento museológico significa a revisão das gramáticas museais, propiciando que patrimônios e museus possam ser disputados por um maior número de atores, materializando os sujeitos subalternizados no bojo de um fluxo cultural intenso que leve à composição de novos regimes de valor, a partir da denúncia dos regimes de colonialidade imperantes.

\section{OS MUSEUS NA MODERNIDADE: UM BREVE HISTÓRICO SOBRE PENSAMENTO E MATÉRIA}

Na história da filosofia moderna, a mente, como entidade separada de um corpo, já se definia, desde Aristóteles, como o único caminho à verdade. Depois, a realidade foi decomposta por Platão entre sua dimensão sensível, que é material, e logo inconsistente ou perecível, e a dimensão formal ou ideal, que pode ser apreendida pelo intelecto. A Modernidade europeia iria levar tal premissa às últimas consequências com Descartes e o método racionalista. No cogito cartesiano, o sujeito pensante seria concebido como uma "mente" completamente separada da materialidade do corpo. Esse pensamento supostamente autônomo da matéria teria reflexos políticos - e, certamente, materiais - que chegam aos nossos dias como herança do passado colonial, testemunhado nas coleções dos museus.

No bojo do lluminismo, com o desenvolvimento dos primeiros museus, a matéria apresentada como evidência de um conhecimento racional seria mediada pela mente desse sujeito cartesiano desprovido de um corpo, passando a ser organizada e classificada de acordo com critérios "verdadeiros", "universais" e centrados no pensamento segundo vinha sendo concebido no contexto europeu. Com os gabinetes de curiosidades na Europa, ainda no século XVIII, a primazia da racionalidade do homem moderno produzia uma mudança de perspectiva sobre o mundo natural que marcava a relação humana com a realidade, enfatizando materialmente a separação entre sujeito e objeto preconizada pelo pensamento filosófico ocidental.

O mundo da terra e do mar, do processamento de alimentos, da produção, deixa de ser um domínio dos trabalhadores e torna-se parte dos interesses dos homens cultivados. Tal mudança estava ligada à transformação da visão de um universo arbitrário, de acontecimentos aleatórios da maneira planejada por Deus, para um mundo definido por relações de causa e efeito, no qual acontecimentos físicos e materiais eram vistos como repetitivos e confiáveis, e logo passíveis de 
6. Sobre a origem do colecionismo na Europa moderna, cf. Pearce (2010).

7. Este é o caso do Museu Nacional do Rio de Janeiro, segundo Maria Margaret Lopes (2009 [1997]), no início do século XIX.

8. Sobre a dominação de imaginários por meio da colonização, cf. Gruzinski (2007).

9. Cf. Pomian (1990); Schaer (2007); Poulot (2009).

10. O projeto conhecido como M/C (Modernidade/ Colonialidade), oriundo da virada para o século XXI, é composto por um conjunto de pesquisas interdisciplinares de acadêmicos da América Latina que apontam para a colonialidade na configuração dos Sistemas-Mundo Modernos, segundo definido por Immanuel Wallerstein. Compõem esse grupo de autores ditos "decoloniais" nomes como os de Walter Mignolo, Enrique Dussel, Aníbal Quijano, María Lugones, Edgardo Lander, Catherine Walsh, Arturo Escobar, Fernando Coronil, entre outros.

11. Cf., por exemplo, a obra de Enrique Dussel (1995), The invention of the Americas, em que o autor defende a ideia de que a Modernidade é algo que diz respeito ao "Terceiro mundo", às ex-colônias, tanto quanto à Europa, e aponta o marco de seu surgimento no ano de 1492, momento da incorporação da Ameríndia no projeto moderno europeu. serem dominados pelo conhecimento adquirido. ${ }^{\circ}$ Segundo o paradigma do conhecimento colecionável, cada pedaço de informação era uma evidência - isto é, um fato autossustentado - apresentada por meio de uma coisa material. Com a investigação metódica de Francis Bacon, corpos de informação seriam deduzidos a partir dos objetos por meio de certos procedimentos confiáveis. Decorre desse princípio, obviamente, a necessidade de uma instituição de caráter científico (regida pela razão), com instalações apropriadas para abrigar e tornar inteligível todo o corpo de evidência material coletado.

Aqueles que pensavam esse museu nos diferentes contextos do mundo onde ele foi estabelecido eram cientistas positivistas, cujas ações eram guiadas pelo princípio da difusão do conhecimento e da "instrução". 7 Nesses museus iluministas, a matéria era produzida pela racionalização metódica do mundo - uma via confiável para a dominação dos imaginários ${ }^{8}$ - que colocava em prática uma dominação da matéria pelo pensamento, nesse momento já percebidos como ontologicamente distintos.

A ligação dos museus e sua disseminação na Europa com a ideologia iluminista é marcada historicamente por uma postura assumidamente cientificista dessas instituições em relação aos contextos "desconhecidos" ou "inexplorados" das colônias. Não por acaso, o período das Luzes é quando se pode observar uma multiplicação sem precedentes dos museus no contexto europeu, período este caracterizado como a "Era dos Museus" na Europa pelos historiadores dessa instituição. ${ }^{9}$ Tais museus modernos (e coloniais) são elaborados, então, no bojo do sistema de pensamento racionalista do dito Ocidente, no qual as "coisas" materiais são organizadas de modo que possam ser observadas, contadas, pesadas e medidas pelo cientista enciclopedista que tem por finalidade o controle do mundo por meio do controle do saber.

Essa Modernidade produzida no bojo de um projeto de dominação imperial não se via desvinculada da produção de conhecimento sobre aqueles a quem se almejava dominar. Tal constatação, explorada em profundidade por críticos do projeto moderno europeu, nos apresenta ao menos duas hipóteses fundamentais que servirão de base para a reflexão desenvolvida neste artigo. A primeira, de ordem histórica, sustenta que a Modernidade diz respeito tanto às colônias, e notadamente à América, quanto à metrópole. Diversos autores associados ao grupo que foi intitulado de Modernidade/Colonialidade ${ }^{10}$ argumentam sobre a necessidade da Europa de inventar uma periferia - em termos de mercadorias, de pensamento e de cultura - para se pensar como centro superior. " Tal concepção aponta para a desconstrução de um ponto de vista historiográfico hegemônico sobre o contato da Europa com os outros continentes não europeus, partindo do entendimento de que a metrópole nunca descobriu (des-cobierto) o Outro construído como objeto (simbólico 
e material), mas encobriu (encobierto) esse Outro, ${ }^{12}$ assimilando-o a um discurso universal e a uma temporalidade única e linear. Nesse sentido, o domínio pelo pensamento significou uma subordinação dos corpos à mente do sujeito soberano que esteve na base do conhecimento produzido pelo processo de colonização.

A segunda hipótese, de ordem museológica, pressupõe que, assim como a produção de conhecimento moderno não se deu sem a periferia, os museus modernos na Europa, desde sua criação, foram constituídos como instituições dependentes da relação de subordinação das colônias - e da ideia de um Outro congelado no tempo e nas vitrines herméticas de suas exposições - para que pudessem conformar o discurso civilizatório europeu e, ao mesmo tempo, legitimar o projeto colonial.

No caso brasileiro, desde a criação da Casa dos Pássaros, em 1784, que, de forma expressiva, "colecionou, armazenou e preparou produtos naturais e adornos indígenas para enviar a Lisboa", ${ }^{13}$ o princípio cientificista orientava o colecionismo no Império, levando à constituição de um Museu Nacional, configurando, ainda que nos trópicos, um "museu metropolitano". Lopes aponta que o costume de remeter à metrópole "produções" da natureza do Brasil, incluindo animais, plantas, minerais, adornos indígenas, e mesmo os próprios indígenas, remonta à chegada dos portugueses, tornando-se intensa e sistemática a partir da segunda metade do século XVIIII. ${ }^{14}$

No âmbito desse projeto de dominação política e material, enquanto a metrópole se estruturava como produtora de conhecimento sobre o Novo Mundo, nas colônias criavam-se as estruturas básicas para o abastecimento das coleções e museus europeus. A primeira museologia pensada e praticada no Brasil, logo, caracterizou-se como uma museologia sobre o Outro, e os sujeitos representados nos museus brasileiros teriam sua identidade marcada pela diferença, sendo o propósito dessas instituições a composição de objetos de estudo - e suas ciências correlatas - para a metrópole ilustrada.

Apesar das circunstâncias de sua origem e da centralidade da metrópole portuguesa no período de constituição de suas coleções iniciais, o Museu Nacional, primeira instituição brasileira a materializar o Outro em seu sentido colonial, apresentou mudanças sensíveis, desde o século XIX, observadas nos seus métodos de coleta e de representação dos objetos adquiridos por meio da pesquisa científica. No caso das coleções de etnologia do museu, como demonstrado por Fátima Nascimento, ${ }^{15}$ a observação de campo pelos cientistas coletores seria determinante na exposição dos objetos indígenas que figuravam menos como "troféus", isto é, constituindo "despojos de expedições punitivas" - como nos museus britânicos da época, por exemplo - e mais como testemunhos de culturas em vias de se dar a conhecer.
12. Dussel (1995, p. 12).

13. Lopes (2009 [1997], p. 25-26).

14. Como lembra Lopes (2009 [1997], p. 25-26), o período de consolidação das ciências modernas no âmbito do império português, marcado pelo que foi caracterizado como a crise do antigo sistema colonial na Europa, contou com importantes reformas educacionais, no contexto da política pombalina, que levou a uma maior adesão a essas ciências, tendo como finalidade a preservação do sistema colonial em crise. Não por acaso, foi nas últimas três décadas do século XVIII que Portugal aderiu mais amplamente à Ilustração europeia.

15. Nascimento (2009, p. 36). 
16. Balandier (1951, p. 5).

17. Grosfoguel (2016, p. 28).

18. Ibid., p. 29.

19. Ibid., loc. cit.
É, com efeito, olhando para as situações coloniais específicas, como caracterizou Georges Balandier, que a própria disciplina antropológica passaria a observar como a produção de conhecimento sobre esse Outro colonizado engendra a condição de "assujeitamento" a que foram submetidos os povos não europeus, categorizados como "atrasados, arcaicos ou primitivos". ${ }^{16}$ É como reflexão sobre a colonização que um conjunto de movimentos posteriores, desenvolvidos a partir da segunda metade do século XX, buscou alternativas às relações de dominação, os quais se caracterizaram como movimentos pela descolonização. Tal reflexão tem início no pensamento, para depois se voltar às práticas e às consequências materiais da dominação.

\section{RE-PENSAR O PENSAMENTO: SUPLANTANDO O DUALISMO ONTOLÓGICO}

"Penso, logo existo". A mais famosa frase de Descartes funda, a partir da Europa, uma nova maneira de pensar que iria ser imposta como dominante no bojo de um processo políitico e filosófico que envolvia os museus. Nessa formulação do pensamento introduzida pelo cartesianismo no momento do nascimento do dito mundo moderno, o "Eu" eurocêntrico substitui Deus como a nova fundação do conhecimento e seus atributos passam a constituir a base da secularização dos atributos do Deus cristão. ${ }^{17}$ Esse "Eu", sujeito soberano das ciências e dos museus, é capaz de produzir um conhecimento que é verdadeiro para além das determinações do tempo e do espaço. $\bigcirc$ "Eu" dessa equação produtora de verdades é, então, duplamente qualificado: como neutro, pois funciona como o "olho de Deus", e como universal, pois não se vê condicionado a nenhuma intenção ou passivel a negociações.

Tal afirmação de um "Eu" que é soberano e se aproxima do "olho de Deus", como explica o sociólogo porto-riquenho Ramón Grosfoguel, se sustenta em dois argumentos centrais mantidos por Descartes. $\bigcirc$ primeiro deles se refere ao que ficou entendido na filosofia cartesiana como dualismo ontológico, isto é, a noção de que a mente está indeterminada e incondicionada pelo corpo, ${ }^{18}$ fundada na separação ontológica entre matéria e espírito, que vem desde Platão. Segundo o dualismo ontológico, a mente do sujeito do pensamento se aproxima do Deus cristão, "flutuando no céu, indeterminada por nenhuma influência terrestre que pode produzir conhecimento equivalente à visão do olho de Deus". ${ }^{19}$ 
$\bigcirc$ que esse argumento provoca, de fato, é a primazia da mente sobre o corpo. Mais ainda, a primazia de uma mente, um imaginário, fundado na razão e na ideia de um sujeito que paira sobre as coisas terrestres. Sem o dualismo ontológico, o pensamento estaria corporificado, a mente teria uma substância corporal, e, então, seria condicionada pelo corpo. $\bigcirc$ "penso, logo existo" seria um "penso, logo existo no meu lugar de fala" - noção esta que colocaria em xeque a própria soberania do sujeito soberano europeu. Em outras palavras, a Europa precisou inventar tal separação ontológica entre pensamento e matéria para produzir uma filosofia universal e neutra que não se vê situada em nenhum local de produção, a não ser na tradição grega - esta mesma inventada pelos romanos ${ }^{20}$-, que passaria a funcionar como o mito de origem de toda a produção de conhecimento do mundo classificado como ocidental.

Para caracterizar ainda a produção de conhecimento como neutra, o cartesianismo se pauta num segundo argumento que é epistemológico. Trata-se do método do solipsismo, que afirma ser apenas por meio de um mergulho interior do sujeito, num diálogo introspectivo consigo mesmo, que o "Eu" pode alcançar a certeza na produção de conhecimento. ${ }^{21}$ Tal concepção levaria à ideia da introspecção como um aspecto inerente à cultura europeia a partir da Modernidade, fazendo do homem ilustrado autônomo da religião e apto a inferir sobre as coisas do mundo por meio de uma racionalidade que faria parte inseparável da mente. A hipótese de que o conhecimento poderia se produzir de forma dialógica entre sujeitos diferentes, segundo supõe Grosfoguel, levaria ao desmoronamento dessa pretensão de um "Eu" capaz de produzir certeza em um conhecimento isolado.

Nos museus, a contemplação e o silêncio são produtos de uma concepção da mente que não depende do corpo, mas da introspecção para produzir conhecimento. A introspecção é característica notável das classes burguesas europeias desde o lluminismo, configurando um dos aspectos da instrução da finesse que devia ser adquirida para ter acesso à alta cultura nessas sociedades. ${ }^{22}$ A popularização posterior dessa instituição que servia para instruir o gosto dessas classes e produzir elites cultivadas não fez com que ela perdesse em grande medida o caráter normativo ligado ao ethos da elite europeia, caráter este produtor de exclusões nas mais diversas ordens.

A visita a um museu dito tradicional e ortodoxo - modelo importado que chega ao Brasil com a colonização - produz o desconforto dos corpos, o silêncio que previne os diálogos que só podem se dar sussurrados em suas galerias assépticas, que servem prioritariamente para fazer pensar sem corpo. Museu é lugar de pensar - é o que dizem os manuais de conduta em muitas dessas instituições europeias até o presente. Porém, pensar sem corpo também pode configurar um modo de
20. Como aponta Muniz Sodré (2017, p. 9) de maneira provocativa, grego nenhum jamais levantou a bandeira da exclusividade do começo da filosofia e da civilização na Grécia. A própria designação de "grego" é posterior, sendo o termo heleno utilizado para se referir a eólios, dórios, aqueus e jônios, antes de o mundo helênico ser apropriado no império romano.

21. Grosfoguel (Op. cit., p. 29).

22. Gay (1996, p. 12). 
eliminação de sensibilidades e presenças não previstas nos regimes de valor que engendram patrimônios e museus aos moldes de um padrão eurocêntrico já em crise.

A exclusão do corpo no processo do pensamento museal faz da produção de ciência nos museus um procedimento neutro e universal baseado no apagamento dos contextos e dos corpos envolvidos no encontro colonial. Para além de um pressuposto filosófico, trata-se de uma postura política que eleva o cientista ou o produtor de conhecimento para a metrópole à posição divina e submete seus objetos à condição subalterna de objetos de museu. Tais apagamentos se veem materializados nas coleções herdadas do passado e são progressivamente denunciados por alguns cientistas do presente. Tomando como exemplo as coleções que constituíam o acervo etnológico do Museu Nacional, tendo atravessado o século XIX, como chama a atenção João Pacheco de Oliveira, estas estavam "absolutamente perpassadas de historicidade, que thes foi investida no próprio contexto de sua coleta". Os objetos, reconsiderados pelo antropólogo do museu, guardam em sua materialidade a própria história do apagamento dos sujeitos indígenas e da colonização:

[...] flechas, arcos, colares, bordunas e cocares usados por líderes indígenas - correspondem a presentes ofertados pelos dirigentes indígenas por ocasião de seu batismo cristão, como prova de amizade e de celebração da paz com os brancos. São em geral peças extremamente valiosas e singulares, pois provêm de pessoas e coletividades historicamente definidas, que se despojavam de bens culturais raros para estabelecer uma relação de aliança e de submissão ao imperador e seus representantes. ${ }^{23}$

A racionalidade cartesiana, ao separar o sujeito (coletor) do objeto (de coleta dos museus) engendra as representações de sujeitos sem corpos e destituídos de sua historicidade como assujeitados aos regimes de colonialidade que fundaram a musealização. É, portanto, preciso re-pensar o pensamento: este que nos chega como um instrumento de exclusão material e simbólica dos corpos que não podem ser pensados - isso porque, ao longo dos últimos séculos, alguns corpos não foram entendidos como corpos que pensam.

\section{A MODERNIDADE NOS MUSEUS E NO PENSAMENTO MUSEOLÓGICO}

Sobre o início da formulação das ciências modernas, fomentado pelos regimes museais dos séculos XVIII e XIX, podemos observar uma primeira musealização da realidade que se dá pela "purificação" da matéria. $\bigcirc$ ser humano - bem como as ciências a ele associadas - é, então, separado de sua 
própria natureza, no bojo de um processo que visa fundar a primeira história, a história da natureza, ${ }^{24}$ uma história que subordina toda a matéria do mundo a um pensamento universal e deslocalizado. Como explicou Lopes, os gabinetes e jardins de História Natural, a partir de meados do século XVIII, passam a substituir os antigos mostruários por exposições catalogadas ${ }^{25}$ que se tornam um modo de produzir uma linguagem de ordenação sobre o mundo. Essa ordem, finalidade do pensamento museal imperial, faria das ciências, mais do que um conjunto de conhecimentos, uma atividade ligada a um saber-fazer produtivista e eurocentrado.

Ao longo do século XIX, aprofundando esse projeto e baseando-se nas principais instituições científicas da Europa - notadamente o Muséum de História Natural de Paris, criado em 1793 - o Museu Nacional do Rio de Janeiro buscava se legitimar como um centro de instrução pública, incorporando o ensino da História Natural para uma elite civilizada, projeto amplamente discutido nas décadas de 1830 e 1840, ${ }^{26}$ contudo não concretizado até o final desse século. Mais tarde, com a configuração do Museu Paraense de História Natural e Etnologia, em 1871, que já nascia com a finalidade de se constituir o "primeiro núcleo de um estabelecimento de ensino superior" no Pará, ${ }^{27}$ a relação dos museus de História Natural com a educação dos brasileiros iria conferir um caráter instrutivo a essa museologia cientificista.

Tal mudança se torna expressiva com a reformulação do Museu Paraense, a partir de 1894, sob responsabilidade do zoólogo suíço Emílio Goeldi, que re-apresentou para os habitantes de Belém do Pará um mundo novo de ciência e civilização. Com a vocação de instituição pública despertada nos museus brasileiros, evidentemente influenciados por museus europeus como o Louvre ou - British Museum - e não mais o próprio Muséum de História Natural, ao menos no que dizia respeito à visitação -, resultou na transformação para uma museologia da curiosidade visando atrair um público mais amplo de não especialistas para descobrir o que essas instituições enciclopédicas guardavam.

A lógica da curiosidade se perpetuava como parte desses museus, quando a questão do público passava a ser valorizada para justificar nacionalmente a relevância dessas instituições. No Brasil republicano, sem que os museus nacionais servissem a interesses específicos da antiga metrópole, o Museu Paraense tentava se consolidar na burocracia estadual, tendo que atrair e cativar a população de Belém, o que era fundamental para a obtenção de recursos. ${ }^{28}$

Para o Museu Nacional do Rio de Janeiro, aberto à visitação em 1821 , a preocupação com o público e as exposições com a apresentação de conteúdos específicos se configuraram a partir da segunda metade do século, como comenta Nascimento, com a exposição dos produtos da Comissão do Império efetuada no Ceará, em 1861, e mais expressivamente após 1882, a partir da Exposição
24. Foucault (2007 [1966], p. 175-177).

25. Lopes (2009 [1997], p. 13).

26. No contexto dessas duas décadas, os ministros dos Negócios do Império e deputados discutiam a possibilidade de se instalar um curso ou uma Faculdade de Ciências Naturais no Museu Nacional, no contexto das discussões sobre a criação de uma universidade no Brasil. O projeto, que não chegou a ser implementado, mobilizou a elite científica ligada ao museu, visando concretizar a sua missão de instrução pública para manter o seu caráter metropolitano. Lopes (2009 [1997], p. 79).

27. O regulamento do Museu Paraense previa "as bases do futuro desenvolvimento dos estudos superiores" na Amazônia, incluindo lições públicas a serem ministradas semanalmente por um membro do conselho administrativo do museu, tal qual seria feito anos mais tarde no Museu Nacional do Rio de Janeiro.

28. Em 1900, o museu alcança um novo recorde de público, quando 2.920 pessoas visitaram em um único dia uma mostra de fotografias e desenhos organizada para a celebração do quarto centenário da descoberta do Brasil. No início do século, o museu tinha os seus índices de público comparáveis ao do Museu Nacional, sendo o primeiro museu ao Norte do país, mais visitado do que aquele na capital federal, segundo afirmava o seu diretor. Sanjad, (2006, p. 172). 
29. A Exposição Antropológica Brasileira, idealizada por Ladislau Netto a partir de 1879, quando este ocupava a direção do Museu Nacional, tem origem no interesse do Império do Brasil em divulgar a Ciência no país. A exposição atrairia diversas doações de objetos e investimentos para o museu, visando enriquecer as bases do que se entendia por "ciência" na época. No ano que a antecedeu, foram realizadas expedições a aldeias indígenas e escavações arqueológicas coordenadas pelos cientistas do museu. A exposição é inaugurada no prédio do Museu Nacional em 29 de julho de 1882. Cf. Nascimento (2009).

30. Oliveira; Santos (2016, p. 17-18).

31. Schwarcz (2008, p. 83).

32. Sobre o desenvolvimento das tipologias ligadas à raça no Brasil, cf. Seyferth (1995).
Antropológica. ${ }^{29}$ Essas primeiras exposições contribuíam para produzir o efeito de uma "ilusão museal", definida por Oliveira e Santos como a enunciação performativa de uma certeza sobre o passado a partir de objetos e imagens "especificamente remetidos ao distante e obtidos por múltiplas formas". ${ }^{30} \bigcirc$ apagamento do contexto de coleta dos objetos signos de um passado criado para ser herdado como verdade produzia, segundo os autores, "imagens e narrativas que justificavam e legitimavam o empreendimento colonial".

A questão do público (propositalmente aceito no singular) criava para os museus brasileiros a reificação de uma categoria social ontologicamente separada das coleções científicas e, logo, dos cientistas que as constituíam e as estudavam, mantendo nos museus ditos modernos a separação entre produtores de conhecimento e consumidores de curiosidades, própria ao pensamento europeu na base dos museus enciclopédicos. Tal separação, dentro da qual se conjugava uma hierarquia social particularmente aguda no contexto brasileiro, foi reproduzida pelos museus até muito recentemente, o que leva uma grande parte da sociedade brasileira no presente a se perguntar sobre a real importância material e simbólica - dessas instituições para o público comum.

Destinados a cumprir, nas colônias, uma missão civilizacional, os museus se fizeram instituições políticas portadores de um ensinamento para populações que não possuíam "instrução". Desde o século XIX, uma lógica positiva iria engendrar hierarquias sensíveis entre os museus e seus públicos no Brasil. As ciências humanas e sociais no país iriam ser criadas partindo do mesmo princípio para engendrar um conhecimento distinto do saber popular, ao mesmo tempo pensado como positivo e ilustrado, no bojo do qual pensamento e matéria se mantinham separados.

Ainda atuando sobre a fragmentação do pensamento, iá no contexto de São Paulo, o Museu Paulista, criado em 1894, a partir de uma coleção particular de moluscos, levaria ao nascimento de uma disciplina antropológica no país, mesmo que vinculada aos parâmetros e modelos das ciências naturais. ${ }^{31}$ Para a antropologia evolucionista da época, estudar o "homem primitivo" não era muito diferente de estudar a flora e a fauna locais. Na verdade, na perspectiva oficial do Museu Paulista, o estudo da humanidade claramente se subordinava a certos ramos do conhecimento científico, em especial a biologia, e só interessava enquanto tal. Assim, no século XIX, os museus brasileiros herdavam dos muséums europeus a definição da Antropologia como o ramo da História Natural que tratava do homem e das raças humanas, tendo por objetivo descobrir as "características permanentes" que permitissem distingui-las enquanto "tipos" biológicos. ${ }^{32}$

Progressivamente, a questão do "povo brasileiro" aliada à ideia de construção da nação preconizada pelos interesses de uma elite paulista que se 
desejava fazer representar na esfera cultural ${ }^{33}$ levou o museu a desenvolver o esboço de ciências humanas e sociais no país. Instalado no Monumento do Ipiranga e herdeiro do famoso quadro de Pedro Américo comemorativo da Independência, o Museu Paulista também não poderia ignorar a sua vocação histórica, criando para o seu público uma representação do que se almejava politicamente como nação. No início do século XX, o museu já constituía um dos principais palcos da imagem nacional, reproduzida em pinturas, tanto quanto nas suas coleções históricas, que, em sua comunicação com o público, exaltavam os heróis da nação, preconizando a supremacia dos paulistas na delimitação das fronteiras externas, bem como no apaziguamento político de tensões internas. ${ }^{34}$ A narração da nação por meio da performance museal, ao mesmo tempo em que produzia uma história nacional, reproduzia colonialidade atribuindo a uma elite política os distintivos da monarquia europeia.

Enquanto performavam a verdade histórica, esses museus nacionais se legitimavam como centros produtores de saber sobre a nação. Tendo por função a organização e a difusão de saberes especializados e, por consequência, o desenvolvimento das ciências no Brasil, os nossos primeiros museus científicos contribuíram para a pulverização do conhecimento ${ }^{35}$ que mais tarde fundamentou-se na divisão em áreas institucionalizadas em faculdades e departamentos nas universidades e centros de pesquisa do país, gerando aquilo que Hilton Japiassu definiu como "patologia do saber". ${ }^{36} \bigcirc$ projeto cientificista que esteve na base da criação do Museu Nacional do Rio de Janeiro, como instituição que servia aos interesses do império português transferido para o Brasil, transpôs para este lado do Atlântico a lógica da produção de conhecimento subordinado ao projeto imperial, em que as metrópoles detêm o saber e os instrumentos de investigação e instrução, e as colônias são percebidas exclusivamente como objetos de estudo para o mundo dito moderno.

\section{A MUSEOLOGIA COMO UM REGIME NORMATIVO}

sentido da produção do conhecimento no mundo dito pós-colonial não pode se ver desvinculado das lógicas de poder e saber que determinam, a partir de relações hierarquizadas, o sujeito soberano das ciências modernas. As noções de "museu" e de "museologia" como categorias importadas no processo de colonização, apropriadas dentro de lógicas de poder e saber estabelecidas pelas metrópoles, devem ser entendidas nesses contextos como categorias negociadas, ou em permanente permuta de significados históricos, políticos e culturais. Tais sentidos resultantes das disputas
33. Schwarcz (Op. cit., p. 90).

34. Sobre a formação, no Museu Paulista, de uma cultura visual que consagrou os bandeirantes como heróis da história e da configuração territorial brasileira, cf. Marins (2007).

35. Cf. Morin (1977).

36. Cf. Japiassu (1976). 
37. Lopes (2009 [1997], p. 160-161).

38. Ibid, p. 165.

39. Nascimento (2009, p. 33). inerentes a uma epistemologia ocidentalizada tendem a informar as práticas locais, contribuindo para a construção de mundos sociais cada vez mais desiguais.

No Brasil, o Museu Nacional nasce, no século XIX, com o propósito de produzir objetos do saber passíveis de serem apropriados, colecionados e domesticados no contexto de uma colônia. Ao longo de quase todo o século, ele seria a principal instância consagradora da ciência e dos seus sujeitos, ao colocar em prática uma museologia sobre o Outro, operando por meio de instrumentos discursivos que moldavam as realidades materiais de acordo com os regimes de valor da ciência racional. Como demonstrou Lopes, nos regulamentos implementados entre 1876 e 1888, entre as seções científicas para a organização do acervo, a Antropologia mesmo que se mantendo como Antropologia Física - separava-se formalmente da Zoologia e das demais ciências naturais, tornando-se uma seção independente e passando a receber grande atenção do diretor Ladislau Netto e do subdiretor da seção, João Batista de Lacerda. ${ }^{37}$ Nesse período iriam se intensificar as excursões de campo, incentivadas por Netto, que tinha a intenção de reunir as anotações das cadernetas dos pesquisadores em uma coleção científica com o título de "Arquivos de Viagens do Museu Nacional". ${ }^{38}$ Tudo se passava como se os sujeitos do saber científico autorizado necessitassem produzir os seus objetos para poderem se legitimar a si mesmos.

Enquanto coletava o Outro para materializar a diferença social constitutiva do Brasil, o museu e seus cientistas musealizavam a si mesmos, reificando a relação entre sujeito e objeto como uma relação de dominação estruturante das instituições museais do país. A matéria produzida por essa instituição, antes mesmo de completar um século de existência, era evidência e testemunho da separação ontológica que herdávamos por meio da Modernidade a que fomos convencidos a aderir.

É revelador que, ao mesmo tempo em que preservava os relatos de campo dos cientistas, o Museu Nacional produzia apagamentos sobre os contextos investigados. No processo de organização de suas coleções que tem início no final do século, logo após a Exposição Antropológica de 1882, o museu reatribui valor aos seus objetos coletados em diferentes contextos e situações coloniais. $\mathrm{Na}$ catalogação dos objetos da coleção antropológica, como ressalta Nascimento, os nomes dos doadores ou coletores seriam substituídos pela designação genérica de "MN", indicando o Museu Nacional como detentor solene do patrimônio e tornando secundárias quaisquer informações sobre o contexto da coleta. ${ }^{39}$

A perda de informação tem por efeito a requalificação simbólica dos objetos no regime museal e a normatização do saber produzido, de forma neutra e deslocalizada, a partir deles. Ao serem reapresentados no museu sem referências precisas sobre a situação da coleta, mas a partir das novas 
disposições informacionais que thes são conferidas, os objetos musealizados são destituídos das implicações políticas de seu passado. A musealização separa a matéria cicatrizada da ferida aberta no momento da colonização. Essa matéria, então, torna-se uma materialização outra, normatizando o presente e apaziguando as narrativas concorrentes sobre o passado.

No contexto dos museus nacionais, essa requalificação tem como consequência, por exemplo, a supressão das perspectivas indígenas e afrobrasileiras sobre o patrimônio "nacional", sendo preconizada uma vertente neutra, universalista e branca da história que sustentaria o projeto de nação e a museologia como uma disciplina normativa - que não meramente estuda os museus e o patrimônio, mas que cria museus e patrimônios dentro de um campo prescritivo determinado pelo sujeito hegemônico. Esse sujeito dos museus e do patrimônio, que é o mesmo sujeito das ciências ocidentalizadas, usurpa do privilégio iluminista de não ter um corpo ou um lugar de fala, levando diversos sujeitos dissidentes a serem silenciados ou a produzirem os seus museus nas margens.

A objetividade científica, preconizada pelos museus e pela museologia acadêmica, reifica e reitera esse sujeito sem corpo, engendrando uma retórica específica, voltada para persuadir atores sociais de que o conhecimento produzido por alguns é o único caminho possível para alcançar a verdade. Assim, a ciência que os museus produzem e legitimam serve, ela mesma, para legitimar e produzir a materialidade dos museus - daí advém a sua relevância política no presente. A soberania do sujeito dessa ciência hegemônica, reificada nos regimes museais e patrimoniais no Brasil, levou à implantação progressiva de uma máquina de apagamentos simbólicos cujos efeitos materiais se aproximam daquilo que alguns autores decoloniais definiram como epistemicídio. ${ }^{40}$

Ao mesmo tempo em que os indígenas eram colocados à margem da sociedade brasileira, o racismo estrutural removia dos seus objetos musealizados os traços da experiência indígena antes da musealização. Nesse processo, a materialidade reificada dos museus e do patrimônio, de acordo com o paradigma do conhecimento não localizado, cria a equivalência ontológica entre artefatos e fatos $^{41}$ e relega aos sujeitos dissidentes o lugar de um "exterior necessário"42 que serve para a manutenção do jogo que produz a hegemonia. A musealização nesses museus nacionais herdeiros de nosso passado colonial realiza a assepsia dos fatos históricos que, como narrado por Oliveira, inviabilizava a produção de contradiscursos mais fiéis à própria experiência dos indígenas. ${ }^{43}$ A ação museal é, portanto, temível, pois exerce o poder de classificar os vivos e docilizar a experiência vivente. 
Como traços contemporâneos de um passado colonial inescapável, os múltiplos exemplos dessa lógica de materialização da assimetria axiológica no patrimônio e nos museus do mundo capitalista pós-colonial não poderiam ser mais flagrantes. Em meados do século XX, com a descentralização do projeto museológico brasileiro, dos grandes museus nacionais para museus populares ou comunitários com enfoque ainda nacionalista, a museologia iria atuar no sentido de conformar as identidades dissidentes ao projeto nacional, produzindo um centro invisível e onipresente. Esse centro de saber descorporificado viria a constituir um ponto de vista deslocalizado do conhecimento museológico, invariavelmente ligado ao colonialismo, ao capitalismo, à supremacia masculina e ao patrimônio eurocentrado. $\bigcirc$ patrimônio e os museus passam a funcionar eles mesmos como o otho de Deus, atuando sobre os imaginários e produzindo a exclusão dos dissidentes que será sistematicamente naturalizada, até estes serem materialmente suprimidos.

\section{REINTEGRANDO A MATÉRIA DOS MUSEUS: EM DIREÇÃO A UMA MUSEOLOGIA INTEGRAL}

A partir da segunda metade do século XX, o campo museal brasileiro se vê marcado por um conjunto de questões sociais em grande parte advindas das diversas formas de apropriação, nos países periféricos, do modelo europeu de museu do século anterior. Com efeito, a transformação eminente que se observa na história dos museus europeus nesse momento decorria de um reconhecimento, no centro da museologia internacional, da existência de formas experimentais de museus nas ex-colônias e da reivindicação por outras museologias que rompessem com o modelo hegemônico disseminado desde a colonização. Essas experiências, ao ganhar visibilidade em âmbito global, se propõem a subverter as lógicas de poder entre metrópoles e colônias, mantidas, até o final do século, pelas ditaduras militares e pelos sistemas econômicos liberais.

A circulação internacional das ideias inovadoras de museólogos e pensadores como Mario Vázquez (México), John Kinard (Estados Unidos), Pablo Toucet (Níger), Stanislas Adotevi (Benin), Marta Ariona (Cuba), Waldisa Rússio (Brasil), entre outros, e a inspiração de figuras como a dos brasileiros Darcy Ribeiro e Paulo Freire fomentaram as novas interpretações sobre o papel social dos museus nas últimas décadas do século XX. Impulsionados, ainda, pelos ecos mais imediatos da Mesa Redonda de Santiago do Chile, organizada pela Unesco, em 1972, e pela noção de "museu integral", elaborada em um contexto particular das ditaduras latino- 
americanas, novas experiências museológicas com viés marcadamente educativo e comunicacional ensaiavam uma virada decolonial inédita na museologia.

Tal virada decolonial foi o resultado de ao menos dois movimentos distintos e paralelos, que tinham início na prática museal para desenvolver formas específicas de pensar o museu na teoria. Enquanto se desenvolviam, na França, a partir do início dos anos 1970, os ecomuseus - museus em que os grupos sociais atuam em sua própria musealização - também nas ex-colônias se apresentavam, com menos visibilidade no contexto internacional, outras experiências inovadoras de "museologias subalternas", 44 de base popular e voltadas para comunidades às margens dos regimes patrimoniais oficiais, que visavam a ruptura, em âmbito local, com o modelo hegemônico de museu europeu. ${ }^{45}$

É nesse sentido que o museu - como dispositivo de poder cunhado para servir aos Estados nacionais na Europa - se faz um instrumento de apropriação patrimonial, por meio do qual é possível reparar danos do passado e reformular as narrativas em que as pessoas estão historicamente inseridas e a partir das quais se constroem os valores do grupo. Os ecomuseus franceses, já inspirados em experiências de museus pós-coloniais, foram a expressão de rupturas que afetavam diretamente o corpo social, provocando demandas por reparação, no sentido de realizar um trabalho de luto, que é, por consequência, um trabalho de luta pela memória, e que foi possível graças à rearticulação ecomuseal entre o patrimônio e a criação cultural. ${ }^{46}$

Segundo o historiador e museólogo mexicano Luis Gerardo Morales Moreno, o museu herdado nas colônias foi concebido pelos europeus como uma forma de "regulação racional das óticas estéticas e descritivas do mundo". 47 A ruptura ideológica e prática com tal premissa permitiu o aparecimento de museologias experimentais locais em consonância com as lógicas e valores dos grupos sociais excluídos dos centros de poder sobre o patrimônio e sobre a matéria a que se atribui valor. Um "olhar mestiço"48 vai levar os museus a reconsiderar o seu papel nas sociedades pós-coloniais e a reintegrar a matéria, por meio de um trabalho de restauração simbólica dos laços com o passado testemunhado em suas coleções.

No Brasil, nos anos 1980, ao mesmo tempo em que a Museologia acadêmica se desenvolvia em centros urbanos brasileiros seletos, múltiplos e revigorados eram os museus que floresciam nas diversas regiões do país. É possível afirmar que o Brasil não havia vivido, até o final do século XX, uma real democratização do país e dos museus, segundo os "preceitos federativos propostos pelo regime republicano instaurado em 1889". 49 Nossa República apresentou vocação para a centralização administrativa e para o forte presidencialismo, características essas que observamos com mais ênfase nos períodos totalitários que marcaram a história brasileira no século XX.
44. Cf. Moreno (2012).

45. Podemos citar o exemplo da Casa del Museo, projeto desenvolvido a partir do final dos anos 1960 pelo museógrafo mexicano Mario Vázquez, que levava para as periferias da Cidade do México objetos do acervo do Museu de Antropologia visando a ressignificação da história pré-colombiana. Vale apontar ainda que é na década de 1970 , no Rio de Janeiro, quando se tem notícia de uma experiência memorial precursora com moradores da favela da Rocinha que participaram da requalificação de suas referências culturais e afetivas com o projeto Varal de lembranças, desenvolvido em parceria com a antropóloga Lygia Segala.

46. Tornatore; Paul (2003, p. 300).

47. Moreno (2012, p. 215).

48. Ibid.

49. Almeida (2006, p. 180). 
O processo de redemocratização dos museus, iniciado nos anos 1980, impulsionado pelo movimento internacional da Nova Museologia, serviu para dar visibilidade a práticas museais comunitárias e participativas, a formas de desenvolvimento local com base no patrimônio e na ressignificação do território como instrumento para o fortalecimento dos laços identitários no interior dos grupos. Não desconectado desse contexto de mudanças, no final da década é criado, como uma iniciativa da equipe de pesquisadores do Setor de Etnologia e Etnografia do Museu Nacional (SEE/MN), sob a coordenação de Pacheco de Oliveira e com a participação de lideranças indígenas da etnia ticuna, o Magüta: Centro de Documentação e Pesquisa do Alto Solimões (CDPAS), que viria a ser, a partir de 1991, o primeiro museu indígena do Brasil. O Museu Magüła, localizado no município de Benjamin Constant, no Amazonas, é criado a partir da articulação dos cientistas do Museu Nacional com as lideranças ticunas, em meio a um cenário de intensas lutas por revalorização de saberes e tradições indígenas, pela demarcação de terras e por direitos sociais. ${ }^{50}$

Este projeto político-cultural de descentralização de algumas ações do Museu Nacional tratou-se, como definido por Andrea Roca, de uma "indigenização do museu"51 que propunha a descolonização dos fazeres museais envolvendo novos atores do patrimônio - antes relegados à categoria de objetos da musealização. Configurava-se um momento de restituição da materialidade do patrimônio para os sujeitos subalternizados que passavam a se apropriar do museu como arena para reivindicações identitárias e por direitos culturais.

Contudo, não se pode ignorar que a chamada Nova Museologia foi um movimento iniciado também por europeus num processo de autocrítica necessária que já foi incorporado ao ethos dos museus contemporâneos nas diversas regiões do mundo. Apesar de deflagrar um questionamento das práticas museais dos museus centrais e de denunciar pela primeira vez o caráter eurocêntrico dessas instituições, a Nova Museologia manteve como premissa a separação ontológica entre sujeito e objeto, entre o pensamento e a realidade material passível de ser apropriada e dominada. Nas novas formas de museus preconizadas, as hierarquias e lógicas de poder características dos museus tradicionais ainda podem ser observadas como análogas àquelas instauradas desde a colonização, e os museus ditos "comunitários" ou "sociais" por vezes contribuem para reificar o lugar marginal do subalterno em vez que romper com o processo de subalternação.

A mesma divisão da realidade preconizada pelo lluminismo racionalista se mantém na base de todo o pensamento que sustentou a Ecomuseologia e a Nova Museologia, como movimentos internacionais de cunho teórico-práticos idealizados a partir da conhecida triangulação que demarca equivalências entre o museu tradicional e os supostos "novos" museus: edifício/território, coleção/ 
patrimônio, público/população. ${ }^{52}$ Nessa demarcação conceitual estruturante dos ecomuseus, sustentada na teoria por autores como Hugues de Varine e André Desvallées, os atores da patrimonialização se mantêm separados do seu patrimônio por uma cisão ontológica que é herdada desde o lluminismo francês.

No nível filosófico, autores como a museóloga brasileira Waldisa Rússio, responsável por iniciar uma crítica incisiva ao eurocentrismo característico dos museus no Brasil, reproduzem ainda o cogito cartesiano em suas teorizações do museu. Ao definir, em 1981, que o objeto de estudo museológico é o fato museal, ou o fato museológico, entendido como "a relação profunda entre o homem, o sujeito cognoscente, e o objeto", 53 a teórica brasileira separa, mais uma vez, o sujeito da razão - sob influência evidente do cogito - do objeto a ser conhecido, como "aquela parte da realidade à qual o homem pertence, e sobre a qual ele tem o poder para atuar", 54 ambas as partes implicadas no fato museal.

A autora se baseia no pensamento de Anna Gregorová, museóloga tcheca influenciada pelo referencial gnosiológico introduzido na museologia por Zbyněk Z. Stránsky, ${ }^{55}$ que definia o objeto de estudo da disciplina como "relações específicas do homem com a realidade". ${ }^{56}$ Gregorová concebe o sujeito observador do museu como aquele que percebe a totalidade da realidade e ao mesmo tempo se diferencia da realidade observada assumindo uma postura museal para com ela. Essa afirmação filosófica do objeto da museologia reifica a separação entre o homem e a realidade, e pressupõe a existência de uma realidade (material) divorciada da sociedade. Dois problemas sociológicos que nos desafiamos a questionar no bojo de uma museologia decolonial e reflexiva, propondo, a seguir, reintegrar a matéria ao pensamento, e aos sujeitos da musealização, para compreender o lugar político que os museus ocupam em nossas sociedades e encontrar os meios de subverter os enunciados hegemônicos que promovem a exclusão.

\section{DO PENSAMENTO MUSEOLÓGICO À MATÉRIA DAS COISAS}

Ao longo dos últimos dois séculos, os museus e a museologia praticada e pensada a partir de paradigmas engendrados na Modernidade senviram para manter lógicas de poder formuladas a partir da colonização. $\bigcirc$ questionamento reflexivo que nos propomos a fazer sobre tais lógicas depende de uma revisão da matéria das coisas preservadas e transmitidas por essas instituições até o presente. A matéria dos museus, herdeira de um pensamento deslocalizado, hoje é substrato para a sua reinterpretação
52. Cf. Desvallées et al. (1992).

53. Rússio (1981, p. 42).

54. Ibid., loc. cit.

55. Para quem o caráter científico da museologia se basearia em referenciais fenomenológicos e no gnosiológico ou da teoria do conhecimento, i. e., que privilegia a relação sujeito-objeto na produção de conhecimento.

56. Gregorová (1980, p. 19) 
57. Butler (1993, p. 31).

58. Aristóteles apud Butler (1993, p. 31-32).

59. Butler (1993, p. 32). e para que essas instituições possam se reimaginar elas mesmas, evitando a repetição da história dominante no presente ou subvertendo os regimes normativos do passado.

Matéria, do grego hyle, no pensamento filosófico clássico, tem sentido de "geração" ou de "origem", podendo ser relacionada às noções de mater e de matriz (ou ao útero). Tradicionalmente, como aponta a filósofa estadunidense Judith Butler, o vínculo entre matéria, origem e significação sugere "a indissociabilidade das noções gregas clássicas de materialidade e significação", de modo que o que importa de um objeto é a sua matéria. ${ }^{57}$ Em Aristóteles, a matéria tem o sentido de "potencialidade" ou pode ser entendida como "a realização da forma". ${ }^{58}$ Materia, no latim, por sua vez, denota aquilo de que as coisas são feitas, mas também pode significar os nutrientes que funcionam como extensão do corpo da mãe para alimentar os filhos. Matéria é aquilo que constitui um assunto ou que dá suporte para experiências. Em todas essas acepções, a matéria se vê investida da capacidade de originar aquilo a que ela também fornece o princípio de inteligibilidade. ${ }^{59}$

Assim, partindo da equivalência entre materialização e significação que está na base da filosofia grega, Butler sugere que os corpos que importam (bodies that matter, em inglês) são aqueles cuja inteligibilidade é materializada pelo discurso. Em outras palavras, aquilo que se torna inteligível para o pensamento é o que se pode materializar, e é o que tem importância (ou valor).

Se é a inteligibilidade (racional) que permite a materialização, logo aquilo que se entende por matéria depende substancialmente dos regimes de saber e de verdade que produzem a inteligibilidade. $O$ conhecimento produzido pelos museus, as verdades aceitas, elas não são produzidas a partir das coisas, ao contrário, são elas que produzem as coisas materiais valoradas nos regimes museais.

Remontando à separação entre alma e corpo elaborada desde Aristóteles, segundo a qual a alma é potência e, portanto, algo não realizado materialmente, Butler, em sua crítica feminista, questiona a própria noção aristotélica de schema, como a forma que dá ao corpo a sua aparência e determina a sua significação. Com base em Foucault, ela propõe compreender o schema dos corpos como "nexos historicamente contingentes de poder/discurso" para chegar à sua noção de "materialização". Em Vigiar e punir, como observa a autora, a alma é interpretada por Foucault como um instrumento de poder através do qual o corpo do prisioneiro é cultivado e formado. Trata-se aqui de uma reelaboração implícita da formulação aristotélica, por meio da qual Foucault vai sustentar que a "alma" se torna um ideal normativo e normalizador, de acordo com o qual "se forma, se modela, se cultiva e se investe o corpo", um "ideal imaginário" historicamente determinado, em direção ao qual se materializa efetivamente o corpo. 
museu, segundo o sentido aqui proposto, é um dispositivo cultural que produz a materialização de corpos por meio da reiteração de um conjunto de normas que vai determinar discursivamente a materialidade das coisas que serão musealizadas e daquelas que não o serão. A "alma", a inteligibilidade, exerce um poder sobre os corpos que ele representa ao re-apresentar a matéria em discurso. Ela é o "instrumento de uma anatomia política". Para Foucault, "a alma é o cárcere do corpo". 60

Essa sujeição produzida pelo discurso, este assujeitamento, no termo foucaultiano, não é apenas uma subordinação, mas também é uma afirmação e realiza a manutenção dos corpos, como uma forma de colocar o sujeito em um dado lugar, de assujeitá-lo. De maneira muito diferente daquela proposta por Aristóteles, a alma, descrita por Foucault como um instrumento de poder, forma e modela o corpo. ${ }^{61}$ Ela produz sujeitos ao produzir os regimes que os regulam e que os fazem se assujeitar.

Ao se referir não apenas à materialidade do corpo dos prisioneiros, mas também à materialidade do corpo das prisões, Foucault nos propõe reintegrar poder, discurso e matéria de modo que podemos re-pensar as instituições fora da lógica aristotélica. Como instituição dependente de uma materialidade para funcionar como instrumento de poder, o museu moderno se materializa na medida em que está investido de poder. Assim como, para Foucault, não há nenhuma prisão prévia à sua materialização, também não há museu que anteceda a sua materialização.

A materialidade, como concebe Butler, designa certo efeito do poder ou, nas palavras da autora, "é o poder em seus efeitos formativos e constitutivos". Ela acrescenta:

Na medida em que o poder opera com êxito constituindo o terreno de seu objeto, um campo de inteligibilidade, como uma ontologia que se tem como dada, seus efeitos materiais se consideram dados materiais ou fatos primários. Essas positividades materiais aparecem fora do discurso e do poder, como seus referentes incontestáveis, seus significados transcendentais. Mas essa aparição é precisamente o momento no qual o regime de poder/discursivo é mais fortemente dissimulado e mais insidiosamente efetivo. Quando esse efeito material é aceito como um ponto de partida epistemológico, um sine qua non de uma dada argumentação política, o que se dá é um movimento de fundacionalismo empiricista que, ao aceitar este efeito constitutivo como um dado primário, enterra e mascara efetivamente a genealogia das relações de poder pelas quais ele se constituiu. ${ }^{62}$

Mais do que produzir sujeitos subalternos, os museus nacionais científicos dissimulam o sujeito soberano por meio da reprodução de um modelo de poder cujo centro invisível determina tudo que vai se materializar no seu entorno como patrimônio. A história do Museu Nacional aqui evocada atesta a história da materialização da relação de dominação colonial que ainda é constitutiva de
60. Foucault (1977, p. 30) apud Butler (1993, p. 34).

61. Butler (Op. cit., p. 33-34).

62. Ibid, p. 34-35. No original: "Insofar as power operates successfully by constituting an object domain, a field of intelligibility, as a taken-for-granted ontology, its material effects are taken as material data or primary givens. These material positivities appear outside discourse and power, as its incontestable referents, its transcendental signifieds. But this appearance is precisely the moment in which the power/discourse regime is most fully dissimulated and most insidiously effective. When this material effect is taken as an epistemological point of departure, a sine qua non of some political argumentation, this is a move of empiricist foundacionalism that, in accepting this constituted effect as a primary given, successfully buries and masks the genealogy of power relations by which it is constituted." (tradução nossa). 
patrimônios e museologias no presente. Ao representar discursivamente uma matéria que atesta a existência de um Outro distante em relação ao sujeito da ciência, o museu elaborado pela colonização reifica a distância e produz materialmente a exclusão. $\bigcirc$ fato de indígenas ainda terem que lutar por sua existência simbólica nos museus da nação não está desvinculado do projeto político de sua eliminação material dos territórios que ocupam ou dos que poderiam vir a ocupar.

A criação, nas últimas décadas, de museus indígenas ou de instituições culturalmente pautadas na sobreposição dos papéis de sujeito e objeto por meio da automusealização não significou uma ruptura definitiva com os regimes de colonialidade fundantes dos museus. $\bigcirc$ que testemunhamos, de fato, é a apropriação do dispositivo que atribui valor e produz inteligibilidade por aqueles que eram excluídos das arenas de representação. $\bigcirc$ dilema filosófico implicado no fazer museu está demarcado pela própria ideia de representação que, em geral, tem o sentido de "falar por" em vez do de reapresentação, que quer dizer dispor de uma outra maneira. Como já advertido por Spivak, ao representar os subalternos, o intelectual, o cientista racionalista, representa a si mesmo em sua transparência e neutralidade. ${ }^{63}$ Algumas perguntas, então, se impõem sobre a museologia que se propõe reflexiva: o Outro, afinal, pode falar de si mesmo ao se automusealizar? $\bigcirc$ intelectual pode falar do Outro sem subalternizá-lo? Como produzir conhecimento e transmitir patrimônios sem reproduzir as posições hierarquizadas de sujeito e objeto? Poderiam os museus e a museologia escapar a sua colonialidade fundante?

Olhar criticamente para o passado colonial, restituir a matéria dos fatos históricos que levaram a sua produção inteligível implica em colocar em questão a própria soberania dos intelectuais sujeitos da ciência. Nesse sentido, a ciência contemporânea serviria para a desconstrução da própria autoridade científica ou para promover a sua distribuição democrática, reparando as lógicas desiguais que perpetuam os regimes de valor em que estamos inseridos. Em outras palavras, a partir do momento em que os indígenas brasileiros se tornarem os sujeitos de nossos museus nacionais, estaremos mais próximos de sua inclusão no projeto de Estado-nação, possivelmente revertendo a subalternidade ou, ao menos, reconhecendo como nossa herança a ferida colonial.

$\bigcirc$ que a crítica filosófica de Butler desvela nos museus é a construção museal do "corpo descorporificado" do sujeito hegemônico masculino e branco, que ainda domina as narrativas produzidas nas instituições nacionais. $\bigcirc$ projeto de nação implementado no Brasil, com efeito, produziu, com auxílio dos museus, uma inteligibilidade racional masculina - que tem como sujeito esse homem europeizado e sem corpo, ainda que morfologicamente reconhecível - que é dependente da exclusão material de outros corpos. Tal exclusão opera mediante a 
produção de Outros racializados, menos racionais, que são desmaterializados pelos museus na medida em que esses dispositivos do poder materializam corpos racionais dissimulados como apolíticos ou desprovidos de ideologia.

Tal materialização de um imaginário, que assujeita os corpos por meio da repetição ao longo do tempo de certas expressões discursivas, pode ser descrita como "o efeito sedimentador de uma reiteração regulada"64 que forma e conforma os corpos dos sujeitos ao produzir a sua representação. Musealizar é materializar, é dar matéria ao pensamento, e produzir musealidade é uma prática política que implica a criação de uma significação positiva, nas vitrines dos museus e nas sociedades que os concebem.

\section{PENSAMENTO É MATÉRIA: RE-PENSANDO OS MUSEUS NO MUNDO PÓS-COLONIAL}

Os museus criam um discurso sobre a matéria na medida em que produzem matéria. Entendendo museus como instrumentos de poder que materializam a realidade representada em seus dioramas e naturalizada em suas classificações, podemos conceber a função dos museus como a de pensar com as coisas. Matéria e pensamento compõem esse dispositivo de assujeitamento dos corpos e de conformação das sociedades por meio do discurso. Se entendemos os museus como dispositivos de poder ${ }^{65}$ que realizam a materialização, então somos levados a nos perguntar: o que os museus produzem em termos materiais? Como dispositivos de subjetivação, museus podem servir tanto para dominar quanto para subverter as lógicas de dominação, produzindo sujeitos sociais dentro de regimes de poder específicos.

Partindo de tal concepção, algumas questões práticas sobre a ação museal podem ser, então, colocadas: se os museus são dispositivos, quem os manipula? Quem está na posição de sujeito e quem é o objeto produzido por meio da musealização? Fica evidente, enfim, que essas são posições situacionais e que podem ser cambiadas de acordo com os jogos de poder em nome dos quais esse dispositivo é colocado em uso.

Como demonstrado anteriormente, ao produzir materialidades atreladas a significações específicas, os museus contribuem para a reiteração social de certos imaginários e reificam hierarquias. Nos primeiros anos do século XXI, a paisagem museal brasileira se delineou com materialidades contrastantes ao sujeito hegemônico dos museus, ainda que sem provocar nenhum abalo nas estruturas fundamentais desse templo ocidentalizante. As políticas culturais
64. Butler (Op. cit., p. 251252).

65. No sentido do conceito proposto por Giorgio Agamben (2005) a partir da noção introduzida por Foucault. Um dispositivo, no sentido exposto por Agamben, é um conjunto heterogêneo de elementos ou tecnologias, linguístico e não linguístico ao mesmo tempo, que pode ser definido, em si mesmo, como a rede que se estabelece entre esses elementos. O dispositivo se inscreve sempre em uma relação de poder, produzindo enunciados. Assim, o dispositivo cria a realidade que enuncia. 
66. Implementados no bojo da Política Nacional de Museus desenhada pelo Instituto Brasileiro de Museus (Ibram), criado em 2009.

67. Irigaray (1985, p. 76) apud Butler (1993, p. 47) desenhadas para o campo museal no Brasil na última década relegaram a algumas iniciativas experimentais fora do centro hegemônico das materialidades possíveis a responsabilidade social de promover a representação das diferenças e a acomodação de dissonâncias que não se viam - e continuam sem se ver - representadas nos grandes museus das narrativas dominantes.

No entanto, foi na contramão da materialização colonial que ergueu museus e patrimônios no Brasil desde o século XIX que algumas iniciativas expressivas testemunham um processo recente de mudança em curso. Nesta última década, observamos - por exemplo, nos editais de Pontos de Memória, ${ }^{66}$ que materializaram outros sujeitos da musealização, produzindo museus fora dos moldes instituídos, ou no trabalho de socioativismo da Rede de Museologia Social, como um instrumento descentralizado multiplicador de tecnologias sociais para esses museus experimentais, assim como nos museus indígenas já citados - algumas formas materiais de resistência à materialização do sujeito universal do cogito que nos foi imposto. Tais iniciativas permitiram a musealização da diferença nas margens, criando afirmativamente as diferenças ao mesmo tempo que as aceitavam no bojo de um sistema de resistências patrimoniais voltado para a sobrevivência das minorias.

Apesar da multiplicação acelerada desses museus que fazem das margens um espaço de criação contínua de "novas museologias", não se pode ignorar que a transferência subliminar de responsabilidades inerentes à máquina de um Estado democrático isenta os museus centrais de terem que lidar com a produção sistêmica da desigualdade, e permite que a Museologia continue, no centro, sem pensar as suas implicações políticas no presente. Tudo se passa como se essas materialidades outras - negras, indígenas, feministas, LGBTI+, transviadas e dissidentes -, após propor questões estruturais para os museus e para os patrimônios legitimados, acabassem por produzir uma matéria que excede à matéria, ${ }^{67}$ sem de fato alterar o processo mesmo de materialização.

A revolução primeira é, portanto, museológica; em direção a um pensamento que é re-pensamento, pois em vez de formar, de-forma os quadros museais e os regimes patrimoniais que servem para reproduzir hierarquias históricas e materialidades subalternas por meio da musealização. Suplantar o dualismo ontológico nos permite deixar de pensar no patrimônio que não tem corpo, que é produto de uma mente sem raízes, para nos dedicarmos a experimentar todos os usos possíveis dos museus no presente. Entender o museu como um dispositivo para a democracia cultural é o primeiro passo para a construção de políticas públicas que não se voltam para a mera manutenção das margens, mas que servem à constante disputa pelo centro produtor de matérias que importam. 
cenário desigual e instável dos museus brasileiros hoje é reflexo de tentativas sucessivas de incluir novos sujeitos sem repensar a própria estrutura normativa dessas instituições, reintegrando a matéria ao pensamento e colocando em questão a materialização de um patrimônio no singular. Como resultado, a nossa política atual das identidades culturais ainda assegura a existência das manifestações de grupos específicos e patrimônios minoritários, produzindo, em contrapartida, a sua invisibilidade e exclusão, exceto nos fóruns especializados e nas redes informais que se constroem para além da esfera museal dominante.

Em meio a um processo que mescla a exclusão de uns e a exaltação de outros, nos resta, na Museologia, a capacidade de pensar as instituições que produzem matéria e seus substratos materiais. A importância da materialidade extinta do Museu Nacional do Rio de Janeiro, inspiração emocional e imaginativa para este ensaio, estaria na sua função de fazer pensar a materialização. A primeira instituição brasileira destinada à pesquisa científica desenvolveu coleções na medida em que exercitou pensamentos e produziu, em sua materialidade finda, a reflexão crítica sobre as suas próprias estruturas e artefatos.

Não se pensa sem matéria, e todo pensamento tem um corpo - a premissa aqui defendida nos leva a constatar que a perda irreparável das coleções científicas do Museu Nacional da UFRJ, em 2018, é testemunho do valor material do pensamento investido no passado apropriado pelos museus e em seus usos no presente, para a sociedade, para o Estado e para o que entendemos hoje por pesquisa científica no país. Esse museu guardava o que nos torna subsidiários de um conhecimento fundante e nos faz saber que a partir dele um novo futuro com passado pode ser construído. $\bigcirc$ que se perdeu no fogo foi a história de um pensamento construído por objetos e documentos acumulados ao longo de mais de 200 anos. Fomos destituídos da oportunidade de pensar a partir deles, de repensar os usos políticos do passado, reintegrando a matéria à experiência subjetiva, tendo o museu como plataforma e dispositivo da mudança em direção a um futuro descolonizado.

$\bigcirc$ modelo de museu que nos chega com a Modernidade ainda não foi tensionado a ponto de desafiar, nas políticas de Estado ou nas leis, o direito previsto à cultura ou a concepção de que as pessoas que produzem cultura são as responsáveis por ditar os seus próprios instrumentos de valoração cultural. A distinção predatória entre sujeito e objeto ainda se perpetua nos regimes museais baseados na materialização do sujeito universal sem corpo que faz de outros corpos e outras materialidades o seu objeto.

Nesses regimes de dominação, impor o modelo importado a grupos sociais para que se empoderem de seu próprio patrimônio não quer dizer o mesmo que 
permitir a esses grupos definirem materialmente os seus próprios instrumentos de transmissão - isto é, aquilo que eles desejam chamar de "museu" e de "museologia".

Conceber diferentes museologias significa materializar diversos atores (sujeitos/objetos) dos museus, no sentido de uma "multiplicidade radical de saberes locais"68 ou de etnomuseologias radicais. Buscamos, com esta reflexão, identificar que uma museologia plural é o único caminho à descolonização, ressaltando a existência dos múltiplos sujeitos localizados da musealização, de modo a deflagrar - lugar de fala do sujeito dominante, produtor de uma materialidade inquestionada e inquestionável. Expusemos o seu poder, explorando uma crítica ao pensamento museológico que chega aos nossos dias por meio da materialidade dos museus e das pessoas que pensam museus - essas também localizadas.

Descolonizar museus e patrimônios é desnaturalizar a matéria sedimentada nas reservas técnicas dos séculos anteriores para imaginar outras materializações possíveis, para além dos regimes normativos que engendraram a museologia que nos foi legada. Descolonizar o pensamento sobre os museus e a museologia implica reimaginar os sujeitos dos museus, bem como os corpos passíveis à musealização. Isto é, num trabalho de arqueologia de nós mesmos e dos vestígios que escolhemos valorar, reimaginar as materializações possíveis em regimes museais descolonizados. A revisão do pensamento aqui proposta não prevê um abandono do dispositivo museu ou sua extinção para as sociedades do presente, mas a sua reinterpretação nos contextos tocados pela colonização, visando configurar novos regimes de valor para produzir patrimônios. Tal revisão, como demonstramos, compreende repensar o próprio pensamento para se imaginar materialidades outras, patrimônios outros, vidas outras passíveis de serem valoradas. 


\section{REFERÊNCIAS}

LIVROS, ARTIGOS E TESES

AGAMBEN, Giorgio. O que é um dispositivo? Outra travessia, Ilha de Santa Catarina, $\mathrm{n}$. 5, p. 9-16, 2005.

ALMEIDA, Cícero Antônio F. de. Museologias possíveis: "a novidade do Brasil não é só litoral”. Musas, v. 2, p. 178-187, Instituto Brasileiro de Museus (Ibram), 2006.

ASAD, Talal. Anthropology and the Colonial Encounter. Nova York: Humanities, 1973.

BALANDIER, Georges. La situation coloniale : approche théorique. Cabiers internationaux de sociologie [online], v. 11, pp. 44-79, 1951. Paris: Les Presses universitaires de France. Disponível em: <http://classiques.uqac.ca/>. Acesso em: 10 jan. 2012.

BRULON, Bruno. Provocando a Museologia: o pensamento geminal de Zbyněk Z. Stránsky. Anais do Museu Paulista, v. 25, n. 1, p. 403-425, 2017.

BUTLER, Judith. Bodies that matter. On the discursive limits of "sex". Nova York; Londres: Routledge, 1993.

DESVAllÉES, André; DE BARRY, Marie Odile; WASSERMAN, Françoise (coords.). Vagues: une anthologie de la Nouvelle Muséologie. 2v. Collection Museologia. Savigny-le-Temple: W-M.N.E.S., 1992.

DUSSEL, Enrique. The invention of the Americas. Eclipse of the "Other" and the Myth of Modernity. Nova York: Continuum, 1995.

FOUCAULT, Michel. Surveiller et punir. Paris: Gallimard, 2016 [1975].

FOUCAULT, Michel. As palavras e as coisas. Uma arqueologia das ciências humanas. São Paulo: Martins Fontes, 2007 [1966]. 
GAY, Peter. The naked heart. The bourgeois experience: Victoria to Freud. Volume IV. Nova York: Norton, 1996.

GREGOROVÁ, Anna. In: MUWOP: Museological Working Papers/DOTRAM: Documents de Travail en Muséologie. Museology - Science or just practical museum work? Stockholm: ICOM, International Committee for Museology/ICOFOM; Museum of National Antiquities, v. 1, p. 19-21, 1980.

GROSFOGUEL, Ramón. A estrutura do conhecimento nas universidades ocidentalizadas: racismo/sexismo epistêmico e os quatro genocídios/epistemicídios do longo século XVI. Revista Sociedade e Estado, Brasília, v. 31, n. 1, p. 25-49, 2016.

GRUZINSKI, Serge. El pensamiento mestizo. Cultura amerindia y civilización del Renacimiento ( $2^{\mathrm{a}}$ ed.). Barcelona: Paidós, 2007.

HARAWAY, Donna. Situated Knowledges: The Science Question in Feminism and the Privilege of Partial Perspective. Feminist Studies, v. 14, n. 3, p. 575-599, 1988.

JAPIASSU, Hilton. Interdisciplinaridade e patologia do saber. Rio de Janeiro: Imago, 1976.

LOPES, Maria Margaret. O Brasil descobre a pesquisa científica. Os museus e as ciências naturais do século XIX. Brasília: UnB; São Paulo: Hucitec, 2009 [1997].

MARINS, Paulo César Garcez. Nas matas com pose de reis: a representação de bandeirantes e a tradição da retratística monárquica européia. Revista do IEB, n. 44, p. 77-104, fev. 2007.

MIGNOLO, Walter D. Delinking. The rhetoric of modernity, the logic of coloniality and the grammar of de-coloniality. Cultural Studies, n. 21(2-3), p. 449-514, 2007.

MORENO, Luis Gerardo Morales. Museología subalterna (sobre las ruinas de Moctezuma II). Revista de Indias, v. LXXII, n. 254, p. 213-238, 2012.

MORIN, Edgar. O Methodo: 1 - A Natureza da Natureza. Mira-Sintra: Europa-América, 1977.

NASCIMENTO, Fátima Regina. A formação da coleção de indústria bumana no Museu Nacional, século XIX. 2009. Tese (doutorado em Antropologia Social) - Programa de PósGraduação em Antropologia Social - PPGAS. Museu Nacional - UFRJ. Rio de Janeiro, 2009.

OLIVEIRA, João Pacheco de. O retrato de um menino bororo: narrativas sobre o destino dos índios e o horizonte político dos museus. Séculos XIX e XXI. Musas - Revista Brasileira de Museus e Museologia, n. 5, p. 36-59, 2011. 
OLIVEIRA, João Pacheco de; SANTOS, Rita de Cássia Melo. Descolonizando a ilusão museal etnografia de uma proposta expositiva. In: LIMA FILHO, Manuel; ABREU, Regina; ATHIAS, Renato (Orgs.). Museus e atores sociais: perspectivas antropológicas. Recife: UFPE/ABA, 2016, p. 17-55.

PEARCE, Susan. The collecting process and the founding of museums in the sixteenth, seventeenth and eighteenth centuries. In: PETTERSSON, Susanna; HAGEDORN-SAUPE, Monika; JYRKKIÖ, Teijamari; WEIJ, Astrid (eds.). Encouraging collections mobility. A way forward for museums in Europe. Kaivokatu: Finnish National Gallery, 2010, p. 12-32.

POMIAN, Krzysztof. Musée et patrimoine. In: JEUDY, Henri Pierre. (dir.) Patrimoines en folie. Paris: Éd. De la Maison des sciences de l'homme, 1990. p. 177-198.

POULOT, Dominique. Musée et muséologie. Paris: La Découverte, 2009.

QUIJANO, Aníbal. Coloniality of Power, Eurocentrism and Latin America. Nepantla: Views from South, n. 1, v. 3, p. 533-580, 2000.

ROCA, Andrea. Acerca dos processos de indigenização dos museus: uma análise comparativa. Mana, v. 21 n. 1, p. 123-155, 2015. Disponível em: <https://bit.ly/2D3ltly>. Acesso em: 5 ago. 2019.

RÚSSIO, Waldisa. In: MUWOP: Museological Working Papers/DOTRAM: Documents de Travail en Muséologie. Interdisciplinarity in Museology. Stockholm: ICOM, International Committee for Museology/ICOFOM/Museum of National Antiquities, v. 2, p. 56-57, 1981.

RÚSSIO, Waldisa. Existe um passado museológico brasileiro? O Estado de S. Paulo, Suplemento Cultural, Ano III, n. 143, 29 jul. 1979, p. 6-8.

SANJAD, Nelson. A “simpatia do povo” pelo Museu Paraense: raízes históricas. Musas, n. 2, Instituto Brasileiro de Museus (Ibram), p. 171-174, 2006.

SCHAER, Roland. L'invention des musées. Paris: Gallimard; Réunion des musées nationaux, 2007.

SCHWARCZ, Lilia Moritz. O espetáculo das raças. Cientistas, instituições e questão racial no Brasil. 1870-1930. São Paulo: Companhia das Letras, 2008.

SEYFERTH, Giralda. A invenção da raça e o poder discricionário dos estereótipos. Anuário Antropológico, Rio de Janeiro: Tempo Brasileiro, n. 93, p. 175-203, 1995.

SODRÉ, Muniz. Pensar Nagô. Petrópolis: Vozes, 2017. 
SPIVAK, Gayatri Chakravorty. Pode o subalterno falar? Belo Horizonte: UFMG, 2010.

TORNATORE, Jean-Louis; PAUL, Sébastien. Publics ou populations? La démocratie culturelle en question, de l'utopie écomuséale aux «espaces intermédiaires». In: DONNAT, Olivier; TOLILA, Paul (dir.). Le(s) publie(s) de la culture. Politiques publiques et équipements culturels. Paris, Presses de Sciences Po, vol. II (CD-ROM), p. 299-308, 2003.

Artigo apresentado em 01/03/2019. Aprovado em 25/09/2019.

\section{(c) BY}

